Acta Botanica Brasilica - 31(2): 295-308. April-June 2017. doi: 10.1590/0102-33062016abb0296

Review

\title{
Arbuscular mycorrhizal fungi and dark septate fungi in plants associated with aquatic environments
}

\author{
Josy Fraccaro de Marins and Rosilaine Carrenho $0^{2,3}$
}

Received: August 14, 2016

Accepted: February 22, 2017

\begin{abstract}
There have been several reports of symbionts in the roots of plants that live in aquatic environments. Arbuscular mycorrhizal fungi (AMF) are the most common microsymbionts and possibly recolonized the aquatic environment together with plants; however, their functions and the extent of their benefits are unclear. Furthermore, the presence of other groups of fungi, such as dark septate fungi (DSF), with functions supposedly analogous to those of mycorrhizal fungi, has also been reported. The present work provides a compilation of data regarding the presence of arbuscular mycorrhizae in plants from, or under the influence of, aquatic environments, and co-colonization by AMF and DSF. Forty species of non-vascular plants, ferns, fern allies, and gymnosperms from 15 families, and 659 species of angiosperms from 87 families were investigated. From the first group (non-flowering plants) $57 \%$ of the species showed arbuscular mycorrhizal structures in their tissues or roots, whereas among the second group (flowering plants) $71 \%$ had such structures. Among the mycorrhizal angiosperms, $52 \%$ showed arbuscules in their roots. DSF were found in $1 \%$ of non-flowering plants and $5 \%$ of angiosperms. All of these are discussed in this review.
\end{abstract}

Keywords: colonization, flooding, fungal co-occurrence, macrophytes, taxonomic diversity

\section{Introduction}

Arbuscular mycorrhizal fungi (AMF) are obligate endosymbionts that live inside roots of vascular plants in terrestrial environments (Parniske 2008). Outside of roots, they form hyphae that go beyond the limits of the roots to improve the acquisition of water and inorganic nutrients from soil (Smith \& Read 2008). The main benefits of mycorrhizae to the host plant involve improved nutrition, but not all plants depend on this association (Janos 2007). AMF belong to the phylum Glomeromycota (Schüßler et al. 2001). In addition to their benefits to plants, their presence is linked to improvements in soil quality, as a result of a higher soil aggregation and $C$ sequestration mediated by extra-radical hyphae (Solaiman 2014), as well as plant diversity and productivity (Heijden \& Horton 2009).

Arbuscular mycorrhizae (AM) are widely distributed throughout the Earth, with terrestrial environments being the most investigated. This association has been observed

\footnotetext{
${ }^{1}$ Universidade Federal de Goiás, Regional Jataí, BR 364 Km 192, 75801-615, Jataí, GO, Brazil

${ }^{2}$ Departamento do Biologia, Centro de Ciências Biológicas, Universidade Estadual de Maringá, Av. Colombo 5790, 87020-900, Maringá, PR, Brazil

${ }^{*}$ Corresponding author: rcarrenho@uol.com.br
} 
Josy Fraccaro de Marins and Rosilaine Carrenho

in different ecosystems and geographic locations (Brundrett 2009), and as is considered a general rule among terrestrial plants, colonizing plants of all taxonomic groups (Wang \& Qiu 2006).

They are present in a great diversity of environments with the most varied biotic and abiotic characteristics. In Brazil, AMF have been found in the most diverse biomes, including Caatinga, Cerrado, Amazon Forest, and Atlantic Forest, as well as in riparian vegetation and aquatic environments (Carrenho et al. 1997; 2001; Carneiro et al. 1998; Alvarenga et al. 1999; Martins et al. 1999; Santos et al. 2000; Souza 2003; Silva et al. 2005; Peña-Venegas et al. 2007; Marins et al. 2009).

There have been few reports on the occurrence of AMF in aquatic environments. The low number of studies and the few aquatic macrophytes investigated, have severely limited comprehending the scope and functionality of the association of arbuscular mycorrhizae with this group of plants. The first such study (Sondergaard \& Laegaard 1977), and numerous subsequent others, have shown that arbuscular mycorrhiza prevail in plants established in the shore zone of freshwater bodies, probably due to the connectivity between the neighboring terrestrial and aquatic ecosystems.

Knowledge regarding mycorrhizal associations in the terrestrial environment cannot be extrapolated to the aquatic environment because submerged or flooded conditions present stress factor that imposes restrictions to growth in terrestrial plants (Parniske 2008), but not in aquatic macrophytes that are adapted to live in this environment.

In addition to AMF, another group of fungi has been encountered in plant roots; the dark septate fungi (DSF). A polyphyletic aggregate of non-clavicipitaceous endophytes (Rodriguez et al. 2009), DSF are broadly defined by presence of intra-radical dark septate hyphae. DSF lack specialized interfaces for nutrient transfer with their plant partners (Peterson et al. 2008), so the reasons for their positive influence on plants are related to mineralization of the substrate to which the host roots are linked, production of phytohormones, reduction of disease intensity of some fungal pathogens, and reduction of competition between plants (Jumpponen \& Trappe 1998). Their simultaneous presence with AMF has been recorded and the sum of their benefits can be particularly important to host plants.

The present review compiled the results of 62 articles provided with data from studies carried out under natural (in the field) or controlled (experimental) conditions, and published in journals indexed in Scopus (http://www. scopus.com/) and ISI Web of Knowledge (http://portal. isiknowledge.com/), without restriction of publishing date. Search strings included both Boolean operators (and/ or) and the keywords/subjects (and synonyms, singular/ plural forms, and English/American language): arbuscular mycorrhizal fungi, vesicular arbuscular fungi, arbuscular mycorrhiza, vesicular arbuscular mycorrhiza, dark septate fungi, dark septate endophyte, aquatic plants, macrophytes, hydrophytes, root colonization and radical colonization. The information was organized in order to reveal the ecological aspects of the association in the aquatic environment, the range of plants that present mycorrhiza among the major plant groups, and the mutual colonization by AMF and DSF, the later a group commonly observed in macrophytes.

\section{Aquatic plants}

Aquatic plants, or macrophytes, are plants that are visible to the naked eye, and whose photosynthetically active parts are permanently, or for several months a year at least, totally or partially submerged, or floating, in fresh or brackish water (Irgang \& Gastal 1996 apud Pott $\&$ Pott 2000). These plants belong to different taxonomic groups, from bryophytes to angiosperms, and represent lineages that left the terrestrial environment and returned to the aquatic environment during their evolution, where they gradually became adapted. Among the primitive angiosperms (paleoherbs), Nymphaeaceae, Cabombaceae and Ceratophyllaceae are common in water bodies. Aquatic monocotyledons are more numerous than eudicotyledons, and out of all the angiosperms living in or close to rivers, lakes, streams and other aquatic systems, about 52 percent belong to monocotyledon families (Scremin-Dias 2009).

Independent of their taxonomic group, macrophytes are classified according to their biological type, that is, their position in the water. Submerged species possess roots fixed in the sediment; therefore, they inhabit the deepest sites of the aquatic environment. There are rooted macrophytes with floating leaves and emergent species that generally occupy the marginal zone of aquatic environments. There are also free-floating species whose roots are not fixed in the sediment (Bianchini-Junior 2003; Thomaz et al. 2004).

Aquatic plants are distinguished from terrestrial plants by possessing anatomical, physiological and ecological particularities. Submerged plants possess numerous adaptations to the limiting conditions to which they are subjected. Gases $\left(\mathrm{O}_{2}\right.$ and $\left.\mathrm{CO}_{2}\right)$ diffuse at extremely low rates in water, and this restricts plant growth. Macrophytes have evolved a number of strategies to ensure the acquisition of $\mathrm{CO}_{2}$, a key element for photosynthesis, and $\mathrm{O}_{2}$, necessary for respiration (Bornette \& Pujijalon 2011). Formation of floating or aerial leaves and aerenchyma are the most common of these adaptations. Other strategies related to photosynthesis include the use of alternative sources of carbon (like bicarbonate) and metabolic pathways for $\mathrm{CO}_{2}$ fixation $\left(\mathrm{C}_{4}\right.$ or crassulacean acid metabolism). In order to alleviate the damage caused by light limitation, submerged plants possess increased chlorophyll content in their leaves, and produce a larger number of chloroplast-containing cells, generally near the upper epidermis (Bornette \& Pujijalon 2011). 


\section{Arbuscular mycorrhizae in aquatic ecosystems}

Until the mid-1970s, it was believed that plants from aquatic ecosystems (macrophytes) did not possess AM associations. There had been reports of the presence of AMF spores in mud near the roots of some plants, but these plants were not colonized (Khan 1974).The first publication of arbuscular mycorrhiza in the aquatic environment was that by Sondergaard \& Laegaard (1977), in which vesicles and/or arbuscules were documented in five species from oligotrophic lakes in Denmark.

In spite of this finding, symbiosis was initially considered to be a rare phenomenon in the aquatic environment (Ragupathy et al. 1990); however, an increase in published research has shown that it is indeed a quite common (SrajKrzic et al. 2006). The frequency of arbuscules and vesicles in aquatic plant roots is low, which hampers the confirmation of colonization (Radhika \& Rodrigues 2007).

Reports of arbuscular mycorrhiza in aquatic ecosystems are more common in plants of fresh or brackish waters, such as streams, lakes, swamps, marshes, estuaries and mangroves (Khan 1974; Beck-Nielsen \& Madsen 2001; Fuchs \& Haselwandter 2004; Wang et al. 2010), than in those from the marine environments, because high salinity and low oxygen content in the sediment do not permit the existence of these fungi (Nielsen et al. 1999).

Soon after the first report of the occurrence of AM in an aquatic environment, a series of investigations began with the aim of better understanding the role of biotic and abiotic factors in the formation of this symbiosis. The presence and morphology of root hairs were the first characteristics evaluated in order to assess the different levels of mycorrhizal dependence (Baylis 1975). Studies in the terrestrial environment have related the absence of root hairs to the presence of mycorrhizae, since it was hypothesized that the fungi would increase the absorption surface in the absence of the hairs. This hypothesis was proposed, and initially confirmed, in the aquatic environment by Sondergaard \& Laegaard (1977), Clayton \& Bagyaraj (1984) and Farmer (1985). However, Bagyaraj et al. (1979) documented the occurrence of hairs in mycorrhizal plants, and Beck-Nielsen \& Madsen (2001) found no clear relationship between the presence of root hairs and AM colonization. These latter authors evaluated submerged and emergent plants in lakes and streams and found that in the first environment the relationship between root hairs and mycorrhizal colonization was more closed but in the second this was not true. Differences in the concentration of nutrients (higher in lakes due to accumulation over time) could be responsible for these contrasting results. Wang \& Qiu (2006) suggested that colonization in aquatic environments or those subject to flooding, which do not have nutrient restriction, and the development of many root hairs, may be factors that cause some species to not be colonized. Other factors are likely also involved, such as those highlighted below.

In a study that compared the diverse lifestyles of submerged plants with the occurrence of AMF, Ragupathy et al. (1990) found that species whose roots were fixed in deeper strata possessed the highest percentages of AM colonization, whereas plants that inhabited shallow floodplains (amphibious, hydrophyte or free-floating) possessed lower percentages of colonization. Sraj-Krzic et al. (2006), on the other hand, found that the number of arbuscules and vesicles was greater in emergent species than in submerged species.

The roots of aquatic macrophytes take in $\mathrm{CO}_{2}$ from the environment, which is used in photosynthesis, and then liberate the resultant product of $\mathrm{O}_{2}$ into the environment. The interior of aquatic macrophytes contains a system of spaces formed by aerenchyma, which accumulate and transport gases and enables exchange with the aquatic environment (Bagger \& Madsen 2004). Aerenchyma has an important role in the transport of gases, and its concentration can influence the frequency of mycorrhizal colonization (Wigand et al. 1998). Cornwell et al. (2001) found high percentages of root colonization by AMF (35\%-55\%) to be related to small quantities of aerenchyma; however, Nielsen et al. (2004) observed the exact opposite (i.e. much aerenchyma and high colonization; 28\%-83\%). Sraj-Krzic et al. (2006) found that the quantity of aerenchyma does not differ between emergent or submerged species, contradicting the validity of the AM frequency/quantity of aerenchyma hypothesis.

Water level is another important environmental factor, which seems to systematically influence AM colonization. Observations in lakes of different depths indicate that AM colonization tends to diminish with increasing depth because of the decline in oxygen concentration (Fiorucci $\&$ Benedetti Filho 2005). Some species are more tolerant to hypoxia, like Ranunculus rivularis Spreng and Pratia perpusilla (Hook.f.) Hook.f., both collected at a depth of three meters. On the other hand, Ruppia polycarpa R. Mason was mycorrhizal at a depth of only half a meter (Clayton \& Bagyaraj 1984).

The fluctuating water level of floodplains causes alternations between flooding and non-flooding, which affects community dynamics of plants and, consequently, other organisms related to this community. Escudero \& Mendoza (2005) and Ray \& Inouye (2006) found AM colonization to occur during both flooding and nonflooding periods; however, the frequency of colonization and numbers of hyphae, arbuscules and spores were greater during the non-flooding period. This finding may be a result of the fluctuating water level markedly altering the oxygen concentration, as has been previously suggested (Ray \& Inouye 2006; Sraj-Krzic et al. 2006).

In the tropics, the impact of flooding on the availability of dissolved oxygen is greater than flooding in temperate 
Josy Fraccaro de Marins and Rosilaine Carrenho

zones because the floods occur when most of plants are experiencing maximal growth rates and reproductive output, which increases the amount of organic matter deposited in the sediment (Bouton et al. 2008). The decomposition of this organic matter increases oxygen consumption even more. In these conditions, the environment can become anoxic, reducing the frequency of root colonization by AMF since they do not grow in anaerobic conditions (Farmer 1985; SrajKrzic et al. 2006). Despite this drawback, Domingos-Neto et al. (2006) found that mycorrhization had a positive effect on the growth of plants of Aster tripolium L. (Asteraceae) cultivated in flood conditions. These authors hypothesized that this response was related to increased efficiency of $\mathrm{N}$ acquisition, as well as via osmotic adjustment resulting in an increase in the amount of ions taken into the root cells of mycorrhizal plants.

Decomposition of organic matter leads to an increase in the concentration of nutrients (solutes) in the water/ sediment, and thus lowers its osmotic potential, thereby limiting the water absorption capacity of roots. So although the environment has more nutrients, they cannot be absorbed because the osmotic potential of the water surrounding the roots is lower than that inside of them. Extra-radical hyphae enhance the absorption of ions (i.e., reduce the solute concentration in water), thereby increasing the osmotic potential outside of roots, and thus their water absorption capacity.

Conversely, a greater availability of phosphorous, arising from the decomposition of organic matter, can also decrease the frequency of arbuscular mycorrhizal colonization (Wigand et al. 1998), which could compromise the transfer of nutrients between the symbionts.

In the terrestrial environment, mycorrhizal fungi are responsible for absorbing nutrients from the soil, and thus are very important for the establishment and growth of plants in natural conditions of soil fertility. Many researchers have studied oligotrophic lakes, hypothesizing a correspondence between the quantity of available nutrients and the establishment of an AM association in these environments. However, this relationship has yet to be confirmed. Clayton \& Bagyaraj (1984) carried out an investigation in twenty-five New Zealand lakes and did not find any relationship between the incidence of mycorrhizal association and the trophic state of the lakes. In experimental studies with several levels of phosphorous, they found that AM colonization occurs at low phosphorous concentrations. White \& Charvat (1999) tested five levels of phosphorous (0; 100; 1,000; 10,000; 47,500 $\mu \mathrm{PO}_{4} \mathrm{~L}^{-1}$ ) and reported that root colonization was highest $(10 \%-30 \%)$ in the three lowest concentrations, and absent in the others. Stevens et al. (2002) also observed that in high concentrations of phosphorous, the frequency of AM colonization decreases, as does the absorption of phosphorous.

The usual high concentration of iron and manganese in the sediment of oligotrophic environments is related to negative interference with absorption, because when these minerals come into contact with oxygen liberated from the roots, their oxidized forms give rise to plaques on root surfaces, which impedes the acquisition of phosphorous, the second most limiting element for plant growth (Christensen \& Wigand 1998). The enzymes of AMF contribute to the solubilization of the metals of the plaques, thereby permitting the absorption of phosphorous (Christensen \& Wigand 1998). Nevertheless, environments with negative redox potentials are often associated with low densities of hyphae (Beck-Nielsen \& Madsen 2001), and under this condition, AMF cease to have any influence on metal dynamics.

Field studies of aquatic ecosystems found that environmental factors that affect plant growth and development (e.g., turbidity, water temperature, $\mathrm{CO}_{2}$ rate, $\mathrm{pH}$, osmotic potential and availability of essential nutrients for photosynthesis, among others) should be taken into account when investigating mycorrhizal symbiosis. Laboratory experiments carried out with Vallisneria americana Michx. (Wigand \& Stevenson 1997) confirmed the importance of an AM association in the aquatic environment. They found that AMF facilitated the acquisition and the assimilation of phosphorous, as well as nitrogen, thereby promoting plant growth and resistance to pathogens. Studies of AMF inoculation in plants of flooded environments indicate that the fungi have the potential to absorb nutrients, mainly during the non-flood period (Jayachandran \& Shetty 2003). In this condition, mycorrhization increases the chances of a plant to survive the stress caused by the lack of nutrients (Sraj-Krzic et al. 2006).

Studies of the composition of neutral lipid fatty acids (NLFA) and phospholipid fatty acids (PLFA), and their ratio, show that mycorrhizae in the aquatic environment are as active and efficient as those in the terrestrial environment (Nielsen et al. 2004). This indicates that the ecological function of these fungi in the aquatic environment is similar to their ecological function in the terrestrial environment.

The activity of AMF in aquatic environments, including areas such as floodplains and wetlands, can also be assessed by means of the quantity of ergosterol, a constituent of the plasma membrane commonly found in fungi (Weete \& Gandhi 1996). Some authors have reported the presence of this group of sterols in extra-radical hyphae and in roots colonized by glomeromycetes (Frey et al. 1992; 1994; Wigand et al. 1998; Fujiyoshi et al. 2000; Hart \& Reader 2002a; b) but most of studies performed in vitro have failed to find it associated with AM structures (Beilby 1980; Beilby \& Kidby 1980; Nordby et al. 1981; Grandmougin-Ferjnai et al. 1999; Fontaine et al. 2001; Olsson et al. 2003). Wigand et al. (1998) identified ergosterol in the roots of Littorella uniflora (L.) Aschers, and found a positive correlation between arbuscular mycorrhizal colonization and the ergosterol index. However, it is worth remembering that the roots evaluated were collected in the field, and so could have been colonized by fungi from other groups and niches (e.g. 
endophytes), which may have masked the result assumed by the authors.

Paleontological (Birks 2000) and molecular (Nielsen et al. 2004) evidence suggest that mycorrhizal fungi that inhabit the aquatic environment are the same as those present in the terrestrial environment. This indicates that plants and AMF recolonized the aquatic environment together. Molecular studies have revealed the presence of 15 AMF species in Cladium jamaicense Crantz, a species native to wetlands (Jayachandran \& Shetty 2003). Escudero \& Mendoza (2005) isolated 15 AMF morphotypes from Lotus glaber Mill., from the pampas of Argentina, but only four of these have been recognized taxonomically (Glomus sp., G. intraradices, G. fasciculatum and Acaulospora sp.). Radhika \& Rodrigues (2007) reported the occurrence of AM in 15 species of macrophytes collected from aquatic and marshy environments in Goa, India with a predominance of Glomus claroideum, which colonized 14 plants, and in Brazil, Marins et al. (2009) identified 27 morphotypes belonging to the genera Glomus and Acaulospora among macrophytes of four water bodies in the upper Paraná River floodplain.

Compared to terrestrial ecosystems, surveys suggest low species diversity within aquatic systems; however, this cannot be assumed to be generally true because diversity disclosure through spores (morphological taxonomy) can be an underestimate if their number is low (Stevens et al. 2002). Furthermore, the collection of spores in this environment is difficult, and no pattern can be established due to the different growth habits of plants. Molecular investigations may be necessary in order to discriminate AMF species associated with the roots of aquatic macrophytes, and to confirm the symbiotic effectiveness of these fungi with regard to the group of plants in question.

\section{A taxonomic approach to the occurrence of AM association with aquatic plants}

In general, macrophytes have been considered nonmycorrhizal plants due to the restrictive conditions of aquatic environments for AMF (Tanner \& Clayton 1985). However, the present study found 62 papers that reported the occurrence of AM associations with a total of 492 of 710 (69\%) species investigated that live in or around an aquatic environment, and being partially or totally submerged during flooding. Of all these reports, only one came from Brazil (Marins et al. 2009). These authors evaluated the occurrence of AM association in nine species of aquatic macrophytes from four lentic environments of the upper Paraná River floodplain (Porto Rico, state of Paraná). They found that species of non-vascular plants (bryophytes), seedless plants (pteridophytes) and basal angiosperms did not possess structures typical of AM association, whereas monocotyledons had occasional AM colonization, and eudicotyledons often had colonized roots. Nevertheless, the percentages of colonization were very low (less than $5 \%$ ) and generally sparse.

The data resulting from the present search showed the presence of arbuscular mycorrhizal structures in almost all groups of plants, but non-vascular plants, ferns and ferns allies, and gymnosperms had only 40 species from 15 families investigated (Fig. 1A). Of the 84 families of angiosperms evaluated, only one did not reveal roots colonized by AMF. From the 659 species of flowering plants found with AM, the greatest occurrence was among campanulids, lamids, and faboids (Fig. 1B).These data are summarized in Tables 1 and 2 (non-flowering plants and angiosperms, respectively). Percentages of colonization varied widely within groups and families (Tabs. S1, S2 in supplementary material), and since all authors did not provide qualitative and/or quantitative data, it is difficult to make inferences about the distribution of DSF. Of the 442 species of angiosperms found by the survey to be colonized by AMF, 228 had arbuscules ( $52 \%$ ); however, given that this information was not provided by all the reports, this is probably an underestimate of the frequency of mycotrophy. A complete list of species and the references cited are available in Tables S1, S2, and list S3 in supplementary material.

\section{Dark septate fungi: who they are, what they do and how do they live?}

Dark septate fungi are sterile or anamorphic endosymbionts that live inside plant tissues without causing negative effects (Jumpponen \& Trappe 1998). Colonization by DSF exhibits four typical morphological structures that are not always present simultaneously: dark septate hyphae (deposition of melanin in the cell wall), hyaline septate hyphae with a lipid reserve, hyaline septate hyphae without a lipid reserve and microsclerotia (Jumpponen \& Trappe 1998). Hyaline hyphae are common during periods of intense plant metabolism, while dark hyphae and microsclerotia appear mainly during later stages of colonization or in periods of stress. Lipid accumulation in hyaline hyphae is believed to be facilitated by the small quantity of melanin and chitin in the cell wall, which seems to facilitate nutrient exchange (Barrow \& Aaltonen 2001). Intra-radical colonization by DSF occurs mostly within the cortex, but hyphae can also reach the vascular cylinder; externally, roots show hyphae and eventually conidiophores (Barrow 2003; Barrow \& Aaltonen 2001).

DSF have been known to science since the beginning of the twentieth century; however, due to the absence of asexual phase in many species, there remain numerous difficulties with the identification. Species such as Aspergillus ustus (Bainier) Thom \& Church (Barrow \& Osuna 2002), Chloridium paucisporum C.J.K. Wang \&H.E. Wilcox, Cryptosporiopsis rhizophila Verkley \& Zijlstra, Heteroconium chaetospira 

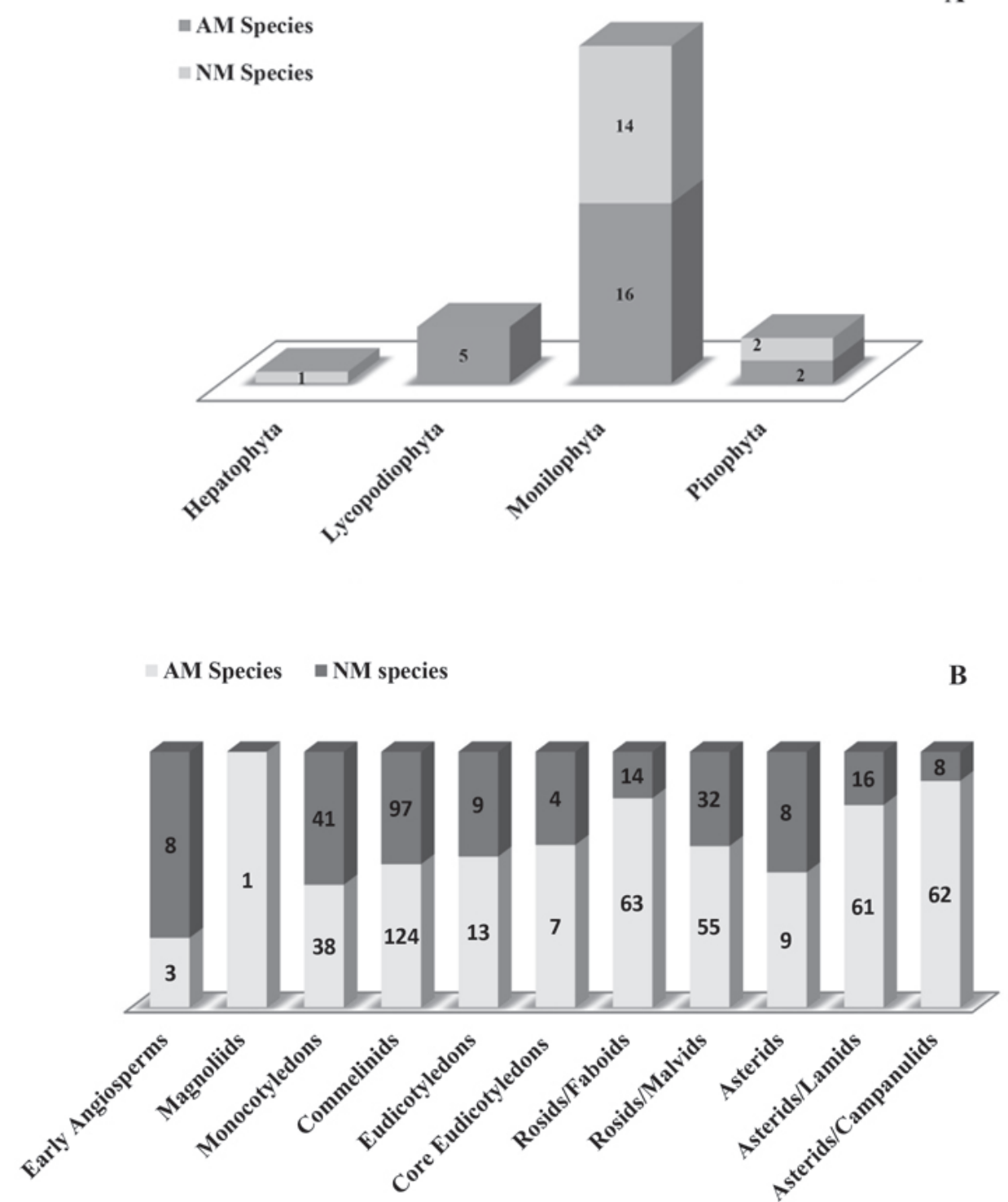

Figure 1. Number of mycorrhizal and non-mycorrhizal associated species for (A) non-flowering, and (B) flowering plants.

(Grove) M.B. Ellis, Leptodontidium orchidicola Sigler \& Currah, Oidiodendron maius G.L. Barron, Phialocephala fortinii C.J.K. Wang \& H.E. Wilcox, P. dimorphospora W.B. Kendr., Phialophora finlandia C.J.K. Wang \& H.E. Wilcox, $P$. graminicola (Deacon) J. Walker, Scytalidium vaccinii Dalpé, Litten \& Sigler and Trichocladium opacum (Corda) S. Hughes (Jumpponen \& Trappe 1998; Addy et al. 2005) were all identified after in vitro cultivation. Of these, Phialocephala fortinii is the most frequently found, and the most studied (Bartholdy et al. 2001; Menkis et al. 2004).

DSF have been observed in different countries of all the regions of the world, such as North America (the United States, Canada, Arctic and the Subarctic), South America (Argentina, Peru), Europe (Germany, United Kingdom, Switzerland, Czeck Republic, among others), Africa (South Africa), Asia (Japan, China, India), Oceania (Australia), and Antarctica (Jumpponen \& Trappe 1998; Ohki et al. 2002; Ruotsalainen et al. 2002; Urcelay 2002; Barrow 2003; Chaurasia et al. 2005; Muthukumar et al. 2006; Weishampel \& Bedford 2006; Li \& Guan 2007; Menoyo et al. 2007). In Brazil, DSF have been observed in a variety of biomes and ecosystems such as the Atlantic Forest in the states of Santa Catarina (Grippa et al. 2007) and Sergipe (Souza 2003), Caatinga in the state of Pernambuco (Santos et al. 2000), Campos Rupestres (rupestrian grasslands) in the state of Minas Gerais (Nogueira et al. 2005) and wetlands in the state of Paraná (Marins et al. 2009).

Jumpponen \& Trappe (1998) pointed out that more than 600 plant species from 114 families possess DSF in their roots. This and other surveys have shown DSF associated with few pteridophytes and many angiosperms and gymnosperms with different survival strategies, including 
Table 1. Reports of presence or absence of arbuscular mycorrhiza in families of non angiosperms growing into or around aquatic environments. AM: arbuscular mycorrhizal; NM: non arbuscular mycorrhizal; TS: total of investigated species; \% AM: percentage of arbuscular mycorrhizal species; DSF+: presence of dark septate fungi; DSF-: ausence of DSF.*

\begin{tabular}{|c|c|c|c|c|c|c|}
\hline Groups & AM & NM & TS & $\%$ AM & DSF+ & DSF- \\
\hline \multicolumn{7}{|l|}{ НЕРАТОРНУТА } \\
\hline \multicolumn{7}{|l|}{ MARCHANTIALES } \\
\hline Ricciaceae & 0 & 1 & 1 & 0 & 1 & 0 \\
\hline \multicolumn{7}{|c|}{ LYCOPODIOPHYTA } \\
\hline \multicolumn{7}{|l|}{ ISOETALES } \\
\hline Isoetaceae & 4 & 0 & 4 & 100 & - & - \\
\hline \multicolumn{7}{|l|}{ LYCOPODIALES } \\
\hline Lycopodiaceae & 1 & 0 & 1 & 100 & - & - \\
\hline \multicolumn{7}{|l|}{ MONILOPHYTA } \\
\hline \multicolumn{7}{|l|}{ EQUISETALES } \\
\hline Equisetaceae & 1 & 1 & 2 & 50 & - & - \\
\hline \multicolumn{7}{|l|}{ OSMUNDALES } \\
\hline Osmundaceae & 1 & 0 & 1 & 100 & - & - \\
\hline \multicolumn{7}{|l|}{ SALVINIALES } \\
\hline Marsilaceae & 1 & 2 & 3 & 33 & - & 2 \\
\hline Salviniaceae & 3 & 6 & 9 & 33 & 3 & - \\
\hline \multicolumn{7}{|l|}{ Polipodiales } \\
\hline Dryopteridaceae & 1 & 1 & 2 & 50 & - & - \\
\hline Davalliaceae & 1 & 0 & 1 & 100 & - & - \\
\hline Onocleaceae & 2 & 0 & 2 & 100 & - & - \\
\hline Pteridaceae & 5 & 0 & 5 & 100 & - & - \\
\hline Thelypteriaceae & 1 & 1 & 2 & 50 & - & - \\
\hline Polypodiaceae & 0 & 3 & 3 & 0 & - & - \\
\hline PINOPHYTA & & & & & - & - \\
\hline Cupressales & & & & & - & - \\
\hline Cupressaceae & 2 & 0 & 2 & 100 & - & - \\
\hline Pinales & & & & & - & - \\
\hline Pinaceae & 0 & 2 & 2 & 0 & - & - \\
\hline Total & 23 & 17 & 40 & & 4 & 2 \\
\hline
\end{tabular}

* List of species is available in Tab. S1 and List S3 in supplementary material.

species that inhabit floodplains (Fuchs \& Haselwandter 2004; Weishampel \& Bedford 2006), aquatic species (SrajKrzic et al. 2006), epiphytic species like orchids (Nogueira et al. 2005) and bromeliads (Grippa et al. 2007), and species that live in semiarid (Muthukumar \& Udaiyan 2002) and arid (Barrow 2003) areas, tropical forests (Souza 2003) and environments subject to freezing (Trowbridge \& Jumpponen 2004) in the Subarctic (Ruotsalainen et al. 2002; Pietikainen et al. 2005), demonstrating the cosmopolitan distribution of these symbionts.

In Brazil, DSF have been observed in bromeliads with distinct growth habits (terrestrial, rocky grassland, and epiphytic) (Grippa et al. 2007), seedlings of Celastraceae, Annonaceae, Anacardiaceae and Myrtaceae (Souza 2003), monocotyledons (Santos et al. 2000), and bryophytes, pteridophytes and angiosperms that live in the aquatic environment (Marins et al. 2009). However, the ecological and physiological aspects of the interaction were not evaluated in any of these studies. Weishampel \& Bedford (2006) pointed out that many studies may confuse colonization by DSF with colonization by AMF, or simply not reported it.

The difficulty in studying this group of organisms is not just with cultivation and the identification of species, but 
Table 2. Reports of presence or absence of arbuscular mycorrhiza in families of angiosperms growing into or around aquatic environments. AM: arbuscular mycorrhizal; NM: non arbuscular mycorrhizal; TS: total of investigated species; \% AM: percentage of arbuscular mycorrhizal species; DSF+: presence of dark septate fungi; DSF-: ausence of DSF.

\begin{tabular}{|c|c|c|c|c|c|c|}
\hline Groups & AM & NM & TS & $\%$ AM & DSF+ & DSF- \\
\hline \multicolumn{7}{|l|}{ Basal Angiosperms } \\
\hline \multicolumn{7}{|l|}{ NYMPHAEALES } \\
\hline Cabombaceae* & $*$ & 1 & 1 & 0 & 1 & 0 \\
\hline Nymphaeaceae & 3 & 7 & 10 & 30 & 0 & 2 \\
\hline \multicolumn{7}{|l|}{ Magnoliids } \\
\hline \multicolumn{7}{|l|}{ LAURALES } \\
\hline Lauraceae & 1 & 0 & 1 & 100 & - & - \\
\hline \multicolumn{7}{|l|}{ Monocotyledons } \\
\hline \multicolumn{7}{|l|}{ ACORALES } \\
\hline Acoraceae & 1 & 0 & 1 & 100 & - & - \\
\hline \multicolumn{7}{|l|}{ ALISMATALES } \\
\hline Alismataceae & 8 & 5 & 13 & 62 & 1 & 2 \\
\hline Aponogetonaceae & 1 & 1 & 2 & 50 & - & - \\
\hline Araceae & 6 & 5 & 11 & 54 & 0 & 1 \\
\hline Hydrocharitaceae & 13 & 12 & 25 & 52 & 1 & 3 \\
\hline Juncaginaceae* & $*$ & 2 & 2 & 0 & - & - \\
\hline Potamogetonaceae & 5 & 14 & 19 & 26 & 1 & 4 \\
\hline \multicolumn{7}{|l|}{ LILIALES } \\
\hline Melanthiaceae & 1 & 0 & 1 & 100 & - & - \\
\hline \multicolumn{7}{|l|}{ ASPARAGALES } \\
\hline Amarylliidaceae & 1 & 0 & 1 & 100 & - & - \\
\hline Asparagaceae* & $*$ & 1 & 1 & 0 & 1 & 0 \\
\hline Iridaceae & 2 & 1 & 3 & 67 & 0 & 1 \\
\hline \multicolumn{7}{|l|}{ Commelinids } \\
\hline \multicolumn{7}{|l|}{ ARECACALES } \\
\hline Arecaceae & 5 & 1 & 6 & 91 & - & - \\
\hline \multicolumn{7}{|l|}{ POAles } \\
\hline Cyperaceae & 40 & 47 & 87 & 46 & 11 & 2 \\
\hline Eriocaulaceae & 1 & 0 & 1 & 100 & - & - \\
\hline Juncaceae & 10 & 8 & 18 & 55 & - & - \\
\hline Poaceae & 55 & 21 & 76 & 72 & 0 & 2 \\
\hline Typhaceae & 6 & 8 & 14 & 43 & 1 & 1 \\
\hline \multicolumn{7}{|l|}{ COMMELINALES } \\
\hline Commelinaceae & 3 & 1 & 4 & 75 & - & - \\
\hline Pontederiaceae & 4 & 2 & 6 & 67 & 1 & 1 \\
\hline \multicolumn{7}{|l|}{ Eudicotyledons } \\
\hline \multicolumn{7}{|l|}{ Ceratophyllales } \\
\hline Ceratophyllaceae & 1 & 2 & 3 & 33 & - & - \\
\hline \multicolumn{7}{|l|}{ RANUNCULALES } \\
\hline Ranunculaceae & 12 & 5 & 17 & 71 & - & - \\
\hline \multicolumn{7}{|l|}{ Proteales } \\
\hline Nelumbonaceae & 0 & 2 & 2 & 0 & 1 & 1 \\
\hline \multicolumn{7}{|c|}{ Core Eudicotyledons } \\
\hline \multicolumn{7}{|l|}{ Rosids } \\
\hline SAXIFRAGALES & & & & & & \\
\hline Crassulaceae & 1 & 0 & 1 & 100 & - & - \\
\hline Grossulariaceae & 1 & 0 & 1 & 100 & - & - \\
\hline Haloragaceae & 5 & 4 & 9 & 56 & 1 & 1 \\
\hline Rosids/Faboids & & & & & & \\
\hline Vitales & & & & & & \\
\hline Vitaceae & 1 & 0 & 1 & 100 & - & - \\
\hline Celastrales & & & & & & \\
\hline Celastraceae & 1 & 0 & 1 & 100 & - & - \\
\hline
\end{tabular}


Table 2. Cont.

\begin{tabular}{|c|c|c|c|c|c|c|}
\hline Groups & AM & NM & TS & $\%$ AM & DSF+ & DSF- \\
\hline Elatinaceae & 2 & 2 & 4 & 50 & 0 & 1 \\
\hline \multicolumn{7}{|l|}{ MALPIGHIALES } \\
\hline Euphorbiaceae & 4 & 0 & 4 & 100 & - & - \\
\hline Hypericaceae & 1 & 0 & 1 & 100 & - & - \\
\hline Rhizophoraceae & 7 & 1 & 8 & 88 & - & - \\
\hline Salicaceae & 6 & 6 & 12 & 50 & 0 & 4 \\
\hline Violaceae & 3 & 0 & 3 & 100 & - & - \\
\hline \multicolumn{7}{|l|}{ FABALES } \\
\hline Fabaceae & 20 & 2 & 22 & 91 & - & - \\
\hline Polygalaceae & 1 & 0 & 1 & 100 & - & - \\
\hline \multicolumn{7}{|l|}{ ROSALES } \\
\hline Rosaceae & 12 & 2 & 14 & 86 & - & - \\
\hline Urticaceae & 1 & 0 & 1 & 100 & - & - \\
\hline \multicolumn{7}{|l|}{ Cucurbitales } \\
\hline Cucurbitaceae & 2 & 0 & 2 & 100 & - & - \\
\hline \multicolumn{7}{|l|}{ FAGALES } \\
\hline Betulaceae & 3 & 1 & 4 & 75 & - & - \\
\hline Casuarinaceae & 1 & 0 & 1 & 100 & - & - \\
\hline \multicolumn{7}{|l|}{ Rosids/Malvids } \\
\hline \multicolumn{7}{|l|}{ GERANIALES } \\
\hline Geraniaceae & 1 & 0 & 1 & 100 & - & - \\
\hline \multicolumn{7}{|l|}{ MyRTALES } \\
\hline Lythraceae & 12 & 0 & 12 & 100 & - & - \\
\hline Onagraceae & 8 & 5 & 13 & 61 & - & - \\
\hline \multicolumn{7}{|l|}{ SAPINDALES } \\
\hline Anacardiaceae & 1 & 0 & 1 & 100 & - & - \\
\hline Meliaceae & 3 & 0 & 3 & 100 & - & - \\
\hline Sapindaceae & 2 & 0 & 2 & 100 & - & - \\
\hline \multicolumn{7}{|l|}{ MALVALES } \\
\hline Malvaceae & 6 & 1 & 7 & 86 & - & - \\
\hline \multicolumn{7}{|l|}{ BRASSICALES } \\
\hline Brassicaceae & 2 & 6 & 8 & 25 & 1 & 0 \\
\hline \multicolumn{7}{|l|}{ SANTALALES } \\
\hline Schoepfiaceae* & $*$ & 1 & 1 & 0 & - & - \\
\hline \multicolumn{7}{|l|}{ CARYOPHYLLALES } \\
\hline Aizoaceae & 1 & 0 & 1 & 100 & - & - \\
\hline Amaranthaceae & 5 & 5 & 10 & 50 & 1 & 0 \\
\hline Droseraceae & 3 & 1 & 4 & 100 & & \\
\hline Montiaceae* & $*$ & 1 & 1 & 0 & 1 & 0 \\
\hline Phytolaccaceae* & $*$ & 1 & 1 & 0 & & \\
\hline Polygonaceae & 11 & 9 & 20 & 55 & 3 & 1 \\
\hline Tamaricaceae & 1 & 0 & 1 & 100 & - & - \\
\hline \multicolumn{7}{|l|}{ Asterids } \\
\hline \multicolumn{7}{|l|}{ CORNALES } \\
\hline Cornaceae & 2 & 0 & 2 & 100 & - & - \\
\hline \multicolumn{7}{|l|}{ ERICALES } \\
\hline Balsaminaceae & 2 & 0 & 2 & 100 & - & - \\
\hline Ericaceae & 1 & 6 & 7 & 14 & 2 & 0 \\
\hline Primulaceae & 4 & 2 & 6 & 67 & & \\
\hline \multicolumn{7}{|c|}{ Asterids/Lamids } \\
\hline GENTIANALES & & & & & & \\
\hline Apocynaceae & 6 & 0 & 6 & 100 & - & - \\
\hline Loganiaceae & 1 & 0 & 1 & 100 & - & - \\
\hline Rubiaceae & 3 & 0 & 3 & 100 & - & - \\
\hline LAMIALES & & & & & & \\
\hline Acanthaceae & 6 & 1 & 7 & 86 & - & - \\
\hline
\end{tabular}


Table 2. Cont.

\begin{tabular}{|c|c|c|c|c|c|c|}
\hline Groups & AM & NM & TS & $\%$ AM & DSF+ & DSF- \\
\hline Calceolariaceae & 1 & 0 & 1 & 100 & - & - \\
\hline Lamiaceae & 12 & 0 & 12 & 100 & - & - \\
\hline Lentibulariaceae* & * & 1 & 1 & 0 & - & - \\
\hline Linderniaceae & 2 & 0 & 2 & 100 & - & - \\
\hline Martyniaceae & 1 & 0 & 1 & 100 & - & - \\
\hline Orobanchaceae* & * & 2 & 2 & 0 & - & - \\
\hline Phrymaceae & 5 & 1 & 6 & 83 & - & - \\
\hline Plantaginaceae & 7 & 6 & 13 & 54 & - & - \\
\hline Scrophulariaceae & 4 & 3 & 7 & 57 & 0 & 1 \\
\hline Verbenaceae & 3 & 0 & 3 & 100 & - & - \\
\hline \multicolumn{7}{|l|}{ SOLANALES } \\
\hline Convolvulaceae & 4 & 0 & 4 & 100 & - & - \\
\hline Hydroleaceae & 1 & 0 & 1 & 100 & - & - \\
\hline Solanaceae & 3 & 1 & 4 & 75 & - & - \\
\hline \multicolumn{7}{|l|}{ BORAGINALES } \\
\hline Sphenocleaceae & 1 & 0 & 1 & 100 & - & - \\
\hline Boraginaceae & 3 & 1 & 4 & 75 & - & - \\
\hline \multicolumn{7}{|c|}{ Asterids/Campanulids } \\
\hline \multicolumn{7}{|l|}{ Asterales } \\
\hline Asteraceae & 42 & 3 & 45 & 93 & 1 & 0 \\
\hline Callyceraceae & 1 & 1 & 2 & 50 & - & - \\
\hline Campanulaceae & 5 & 0 & 5 & 100 & - & - \\
\hline Menyanthaceae & 1 & 2 & 3 & 33 & 1 & 1 \\
\hline \multicolumn{7}{|l|}{ APIALES } \\
\hline Apiaceae & 8 & 2 & 10 & 80 & 1 & 0 \\
\hline Araliaceae & 2 & 0 & 2 & 100 & - & - \\
\hline \multicolumn{7}{|l|}{ Dipsacales } \\
\hline Adoxaceae & 4 & 0 & 4 & 100 & - & - \\
\hline Total & 442 & 227 & $669(-10)^{*}$ & 71 & 31 & 29 \\
\hline
\end{tabular}

* Ten species are related as mycorrhizal and non mycorrhizal, in different studies. The taxonomy of the plants was adjusted according to APG III, available at the Missouri Botanical Garden site (http://www.mobot.org). List of species is available in Tab. S2 and List S3 in supplementary material.

also in understanding the type of interaction that exists between the plant and the fungus. The identified species of DSF are mostly known to be saprophytic, parasitic or pathogenic, because they occur in decomposing plant material or in diseased plants. However, when these fungi are observed inside the tissues of plants that are healthy and without any symptom of disease, they are considered endophytic organisms (Menkis et al. 2004). Several authors have suggested that these fungi are mutualists and perform the same symbiotic function as mycorrhizae (Jumpponen \& Trappe 1998; Jumpponen 2001; Addy et al. 2005). The presence of phosphatases in the active mycelium of these fungi has been documented, and knowing that they participate in the hydrolysis of phosphorous, it is reasonable to suppose that this element is transferred to the plant via the fungus (Barrow \& Osuna 2002; Barrow 2003). The inoculation of Leptodontidium sp. into roots of Saussurea involucrate Matsum. \& Koidz. resulted in increases in plant growth of up to $30 \%$, but it remains unknown whether the growth was stimulated by a altered nutritional condition (mycorrhizal function?) or by a higher production of substances that promote growth (Wu \& Guo 2008). The inoculation of Phialocephala fortini in Pinus contorta Douglas ex. Loudon increased the acquisition of nitrogen and phosphorous by this plant (Jumpponen et al. 1998). Postma et al. (2007) suggested that DSF may have replaced AMF in an area with extremely acidic soil colonized by native herbaceous vegetation. New studies need to be carried out in order to determine what mechanisms trigger mutualistic, parasitic or saprophytic responses in this type of interaction, so that the breadth of the potential niche of DSF may be better understood.

\section{Co-occurrence of AMF and DSF}

There have been several reports of the coexistence of AMF and DSF in terrestrial plants (Ruotsalainen et al. 2002; Fuchs \& Haselwandter 2004; Beauchamp et al. 2005; Cázares et al. 2005; Lingfei et al. 2005; Pietikainen et al. 2005; Muthukumar et al. 2006; Menoyo et al. 2007; Postma et al. 2007). The coexistence of DSF with other mycorrhizal types, 
such as ectomycorrhizae (Horton et al. 1998; Muthukumar \& Udaiyan 2002; Trowbridge \& Jumpponen 2004; Li \& Guan 2007), ericoid mycorrhizae (Johansson 2001; Urcelay 2002; Rains et al., 2003) and orchid mycorrhizae (Valdes et al. 2011), has also been reported.

Under conditions of stress, AM colonization has been observed to decrease or disappear, and DSF colonization has been observed to increase or remain constant, such as in conditions of very low $\mathrm{pH}$ (Postma et al. 2007) or in soils polluted with nickel and copper (Ruotsalainen et al. 2007) or cadmium (Deram et al. 2008). However, the relationship of these fungi with plants in these conditions is yet to be understood. Ruotsalainen et al. (2007) suggested that the presence of melanin and dispersion by microsclerotia facilitate the tolerance of these fungi to unfavorable growth conditions. Lingfei et al. (2005) evaluated colonization by AMF and DSF in grasses for one year, and found that the percentage of AM colonization was significantly correlated with many environmental factors, such as the concentration of phosphorous and precipitation (varying greatly during the year). On the other hand, colonization by DSF was more stable, being affected by only relative humidity and photoperiod. Mandyam \& Jumpponen (2008) also observed the colonization of grasses by AMF and DSF a full year, and found a relationship between colonization and seasonality, and that the growth peak was different for each fungus. Another interesting datum is that nonmycorrhizal plants, like most species of Cyperaceae, can possess high frequencies of colonization by DSF. In these cases, it is believed that these organisms are analogous to mycorrhizal fungi (Jumpponen \& Trappe 1998; Barrow \& Aaltonen 2001).

Wagg et al. (2008) believed that when there is coexistence, the fungi tend to occupy different niches within the same root. Trowbridge \& Jumpponen (2004) verified that there is no antagonistic relationship between AMF and DSF. Until now, most research has reported only the coexistence of DSF and mycorrhizal fungi, but the significance of the interactions between the mycobionts of the two associations and between them and the host plant still needs to be elucidated.

In the aquatic environment, Stevens et al. (2011) proposed a classification for floodplain plants, using their degree of dependence on the hydric condition (obligatory on floodplains; optional on floodplains; optional in terrestrial environments), and tried to correlate it with the colonization of roots by AMF and DSF. The authors did not find a correlation between the hydric categories of plants and the presence of fungi, but observed that the obligate floodplain plants exhibited a negative correlation between colonization by DSF and the frequency of vesicles and hyphae of AMF. In a lake subject to water level fluctuation, AMF and DSF were found co-occurring in Phragmites australis (Cav.) Trinius ex Steud. The occupation of roots by the fungi varied over time, differed among the sampling sites in the lake, and was regulated by the water level, environmental conditions and plant growth stage (Dolinar \& Gaberščik 2010).

Data from our search found the co-occurrence of AMF and DSF (10 papers) in three species of Lycopodiophyta, three species of Monilophyta, none in Pinophyta, early angiosperms and magnoliids, 27 in Monocots and 65 in Eudicots. Nineteen other mycorrhizal plant species showed no DSF colonization. In non-mycorrhizal plants (data from six papers), DSF were observed in one species of Hepatophyta, three in Moniliophyta, one in early angiosperms, 17 in monocots and 11 in eudicots (Tab. 1). Thirty-one other non-mycorrhizal plant species investigated showed no DSF on their roots or in their tissues (Tab. 2).

When fungi coexist, they tend to occupy different niches in the root, thereby minimizing competition (Wagg et al. 2008). Data obtained by Trowbridge \& Jumpponen (2004) confirm this supposition by evaluating the presence of different groups of fungi in roots of certain species of willow and verified that the relationship between AMF and DSF was not antagonistic.

\section{Final consideration}

Knowledge of the importance of associations with AMF and DSF seems essential to the advancement of ecological studies of aquatic macrophytes, since the most evolved plant groups are colonized with no harmful symptoms. Maintenance of the mycobionts produces expenditures for the plant, which should benefit from the association in some way. Studies evaluating the contribution of such associations to the growth and nutrition of plants of the aquatic environment should be carried out in both controlled (tanks in a greenhouse) and in situ situations, in order to evaluate whether these fungi occupy similar niches and perform similar roles in both aquatic and terrestrial ecosystems.

\section{Acknowledgements}

We are grateful to Sandra Maria Gomes da Costa, Liliana Rodrigues, Sandra Andréa Pierini and Roger Paulo Mormul, for serving as members of the evaluation committee of the thesis of Josy Fraccaro de Marins, and to Sidinei Magela Thomas, her co-advisor, that made valorous suggestions to this paper. We also thank Coordenação de Aperfeiçoamento de Pessoal de Nível Superior (CAPES) for the grant provided to the first author.

\section{References}

Addy HD,Piercey MM,Currah RS 2005. Microfungal endophytes in roots. Canadian Journal of Botany 83: 1-13.

Alvarenga MIN, Siqueira JO, Davide AC. 1999. Teor de carbono, biomassa microbiana, agregação e micorriza em solos de Cerrado com diferentes usos. Ciência Agrotécnica 23:617-625. 
Bagger J, Madsen TV. 2004. Morphological acclimation of aquatic Littorella uniflora to sediment $\mathrm{CO}_{2}$ concentration and ware exposure. Functional Ecology Journal 18: 946-951.

Bagyaraj DJ, Manjunath A, Patil RB. 1979. Occurrence of vesiculararbuscular mycorrhizae in some tropical aquatic plants. Transactions of the British Mycological Society 72: 154-156.

Barrow JR. 2003. Atypical morphology of dark septate fungal root endophytes of Bouteloua in arid southwestern USA rangelands. Mycorrhiza 13: 239-247.

Barrow JR, Aaltonen RE. 2001. Evaluation of the internal colonization of Atriplex canescens (Pursh) Nutt. roots by dark septate fungi and the influence of host physiological activity. Mycorrhiza 11: 199-205.

Barrow JR, Osuna P. 2002. Phosphorous solubilization and uptake by dark septate fungi in fourwing saltbush, Atriplex canescens (Pursh) Nutt. Journal of Arid Environments 51: 449-459.

Bartholdy BA, Berreck M, Haselwandter K. 2001. Hydroxamate siderophore synthesis by Phialocephala fortinii, a typical dark septate fungal root endophyte. Biometals 14: 22-42.

Baylis GTS. 1975. The magnolioid mycorrhiza and mycotrophy in root systems derived from it. In: Sanders FE, Mosse B, Tinker PB. (eds.) Endomycorrhizas. London, UK: Academic Press. p. 373-389.

Beauchamp VB, Stromberg JC, Stutz JC. 2005. Interactions between Tamarix ramosissima (saltcedar), Populus fremontii (cottonwood), and mycorrhizal fungi: Effects on seedling growth and plant. Plant and Soil 275: 221-231.

Beck-Nielsen D, Madsen TV. 2001. Occurrence of vesicular-arbuscular mycorrhiza in aquatic macrophytes from lakes and streams. Aquatic Botany 71: 141-148.

Beilby JP. 1980. Fatty acid and sterol composition of ungerminated spores of the vesicular-arbuscular mycorrhizal fungus, Acaulospora laevis. Lipids 15: 949-952.

Beilby JP, Kidby DK. 1980. Sterol composition of ungerminated and germinated spores of the vesicular-arbuscular mycorrhizal fungus, Glomus caledonius. Lipids 15: 375-378.

Bianchini-Junior I. 2003. Modelo de crescimento e decomposição de macrófitas aquáticas. In: Thomaz SM, Bini LM. (eds.) Ecologia e manejo de macrófitas aquáticas. Maringá, EDUEM. p. 85-125.

Birks HH. 2000. Aquatic macrophyte vegetation development in Krakenes Lake, western Norway, during the late-glacial and early-Holocene. Journal of Paleolimnology 23: 7-19.

Bornette G, Puijalon S. 2011. Response of aquatic plants to abiotic factors: a review. Aquatic Science 73: 1-14.

Boulton AJ, Boyero L, Covich AP, Dobson M, Lake S, Pearson R. 2008. Are tropical streams ecologically different from temperate streams? In: Dudgeon D. (ed.) Tropical Stream Ecology. London, Elsevier. p. 257-284.

Brundrett MK. 2009. Mycorrhizal associations and other means of nutrition of vascular plants: understanding the global diversity of host plants by resolving conflicting information and developing reliable means of diagnosis. Plant and Soil 320: 37-77.

Carneiro MAC, Siqueira, JO, Moreira FMS, Carvalho D, Botelho S, Saggin Júnior OJ. 1998. Micorriza arbuscular em espécies arbóreas e arbustivas nativas de ocorrência no sudeste do Brasil. Cerne 4: 129-145.

Carrenho R, Bononi VLR, Barbosa LM. 1997. Glomales em áreas de recomposição de mata ciliar de Moji-Guaçu, SP, Brasil. Hoehnea 24: 107-113.

Carrenho R, Trufem SFB, Bononi VLR. 2001. Fungos micorrízicos arbusculares em rizosferas de três espécies de fitobiontes instaladas em área de mata ciliar revegetada. Acta Botanica Brasilica 15: 115-124.

Cázares E, Trappe JM, Jumpponen A. 2005. Mycorrhiza-plant colonization patterns on a subalpine glacier forefront as a model system of primary succession. Mycorrhiza 15: 405-416.

Chaurasia B, Pandey A, Palni LMS. 2005. Distribution, colonization and diversity of arbuscular mycorrhizal fungi associated with central Himalayan rhododendrons. Forest Ecology and Management 207: 315-324.

Christensen KK, Wigand C. 1998. Formation of root plaques and their influence on tissue phosphorous content in Lobelia dortmanna. Aquatic Botany 61: 111-122.
Clayton JS, Bagyaraj DJ. 1984. Vesicular-arbuscular mycorrhizas in submerged aquatic plants of New Zealand. Aquatic Botany 19: 251-262.

Cornwell WK, Bedford BL, Chapin CT. 2001. Occurrence of arbuscular mycorrhizal fungi in a phosphorous-poor wetland and mycorrhizal response to phosphorous fertilization. American Journal of Botany 88: 1824-1829.

Deram A, Languereau-Leman F, Howsam M, Petit D, Haluwyn CV. 2008. Seasonal patterns of cadmium accumulation in Arrhenatherum elatius (Poaceae): Influence of mycorrhizal and endophytic fungal colonization. Soil Biology and Biochemistry 40: 845-848.

Dolinar N, Gaberščik A. 2010. Mycorrhizal colonization and growth of Phragmites australis in an intermittent wetland. Aquatic Botany 93: 93-98.

Domingos-Neto CLM, Cruz C, Martins-Loução MA. 2006. How do mycorrhizas affect $C$ and $\mathrm{N}$ relationships in flooded Aster tripolium plants? Plant and Soil 279: 51-63.

Escudero V, Mendoza R. 2005. Seasonal variation of arbuscular mycorrhizal fungi in temperature grassland along a wide hydrologic gradient. Mycorrhiza 15: 291-299.

Farmer, AM. 1985. The occurrence of vesicular-arbuscular mycorrhiza in isoetid-type submerged aquatic macrophytes under naturally varying conditions. Aquatic Botany 21: 245-249.

Fiorucci AR, Benedetti-Filho E. 2005. A importância do oxigênio dissolvido em ecossistemas aquáticos. Química Nova na Escola 22: 10-16.

Fontaine J, Grandmougin-Ferjani A, Hartmann M-A, Sancholle M. 2001. Sterol biosynthesis by the arbuscular mycorrhizal fungus Glomus intraradices. Lipids 36: 1357-1363.

Frey B, Buser HR, Schüepp H. 1992. Identification of ergosterol in vesiculararbuscular mycorrhizae. Biology and Fertility of Soils 13: 229-234.

Frey B, Vilarino A, Schüepp H, Arines J. 1994. Chitin and ergosterol content of extraradical and intraradical mycelium of the vesiculararbuscular mycorrhizal fungus Glomus intraradices. Soil Biology and Biochemistry 26: 711-717.

Fuchs B, Haselwandter K. 2004. Red list plants: Colonization by arbuscular mycorrhizal fungi and dark septate endophytes. Mycorrhiza 14: 277-281.

Fujiyoshi M, Nakatsubo T, Ogura S, Horikoshi T. 2000. Estimation of mycelial biomass of arbuscular mycorrhizal fungi associated with the annual legume Kummerowia striata by ergosterol analysis. Ecological Research 15: 121-131.

Grandmougin-Ferjnai A, Dalpé Y, Hartmann M-A, Laurelle F, Sancholle M. 1999. Sterol distribution in arbuscular mycorrhizal fungi. Phytochemistry 50: 1027-1031.

Grippa CAR, Hoeltgebaum MP, Stürmer SL. 2007. Occurrence of arbuscular mycorrhizal fungi in bromeliad species from the tropical Atlantic forest biome in Brazil. Mycorrhiza 17: 235-240.

Hart MM, Reader RJ. 2002a. Taxonomic basis for variation in the colonization strategy of arbuscular mycorrhizal fungi. New Phytologist 153: 335-344.

Hart MM, Reader RJ. 2002b. Host plant benefit from association with arbuscular mycorrhizal fungi: variation due to differences in size of mycelium. Biology and Fertility of Soils 36: 357-366.

Heijden MGA, Horton TR. 2009. Socialism in soil: The importance of mycorrhizal fungal networks for facilitation in natural ecosystems. Journal of Ecology 97: 1139-1150.

Horton TR, Cázares E, Bruns TD. 1998. Ectomycorrhizal, vesiculararbuscular and dark septate fungal colonization of bishop pine (Pinus muricata) seedlings in the first 5 months of growth after wildfire. Mycorrhiza 8: 11-18.

Janos DP. 2007. Plant responsiveness to mycorrhizas differs from dependence upon mycorrhizas. Mycorrhiza 17:75-91.

Jayachandran K, Shetty KG. 2003. Growth response and phosphorous uptake by arbuscular mycorrhizae of wet prairie sawgrass. Aquatic Botany 76: 281-290.

Johansson M. 2001. Fungal associations of Danish Calluna vulgaris roots with special reference to ericoid mycorrhiza. Plant and Soil 231: 225-232,

Jumpponen A. 2001. Dark septate endophytes - are they mycorrhizal? Mycorrhiza 11: 207-211. 
Jumpponen A, Mattson KG, Trappe JM. 1998. Mycorrhizal functioning of Phialocephala fortinii with Pinus contorta on glacier forefront soil: interactions with soil nitrogen and organic matter. Mycorrhiza 7: 261-265.

Jumpponen A, Trappe JM. 1998. Dark septate endophytes: a review of facultative biotrophic root-colonizing fungi. New Phytologist 140: 295-310.

Khan AG. 1974. The occurrence of mycorrhizas in halophytes, hydrophytes and xerophytes, and of Endogone spores in adjacent soils. Journal of General Microbiology 81: 7-14.

Li AR, Guan KY. 2007. Mycorrhizal and dark septate endophytic fungi of Pedicularis species from northwest of Yunnan Province, China. Mycorrhiza 17: 103-109.

Lingfei L, Anna Y, Zhiwei Z. 2005. Seasonality of arbuscular mycorrhizal symbiosis and dark septate endophytes in a grassland site in southwest China. FEMS Microbiology. Ecology 54: 367-373.

Mandyam K, Jumpponen A. 2008. Seasonal and temporal dynamics of arbuscular mycorrhizal and dark septate endophytic fungi in a tallgrass prairie ecosystem are minimally affected by nitrogen enrichment. Mycorrhiza 18: 145-155.

Marins JF, Carrenho R, Thomaz SM. 2009. Occurrence and coexistence of arbuscular mycorrhizal fungi and dark septate fungi in aquatic macrophytes in a tropical river-floodplain system. Aquatic Botany 91: 13-19.

Martins CR, Miranda JCC, Miranda LN. 1999. Contribuição de fungos micorrízicos arbusculares nativos no estabelecimento de Aristida setifolia Kunth em áreas degradadas do Cerrado. Pesquisa Agropecuária Brasileira 34: 665-674.

Menkis A, Allmer J, Vasiliauskas R, Lygis V, Stenlid J, Finlay R. 2004. Ecology and molecular characterization of dark septate fungi from roots, living stems, coarse and fine woody debris. Mycological Research 108: 965-973.

Menoyo E, Becerra AG, Renison D. 2007. Mycorrhizal associations in Polylepis woodlands of Central Argentina. Canadian Journal of Botany 85: 526-531.

Muthukuma T, Senthilkumar M, Rajangam M, Udaiyan K. 2006. Arbuscular mycorrhizal morphology and dark septate fungal associations in medicinal and aromatic plants of Western Ghats, Southern India. Mycorrhiza 17: 11-24.

Muthukumar T, Udaiyan K. 2002. Seasonality of vesicular-arbuscular mycorrhizae in sedges in a semi-arid tropical grassland. Acta Oecologica 23: 337-347.

Nielsen KB, Kjoller R, Schweiger PF, Andersen FO, Rosendahl S. 2004. Colonization and molecular diversity of arbuscular mycorrhizal fungi in the aquatic plants Littorella uniflora and Lobelia dortmanna in southern Sweden. Mycological Research 6: 616-625.

Nielsen SL, Thingstrup I, Wigand C. 1999. Apparent lack of vesiculararbuscular mycorrhiza (VAM) in the seagrasses Zostera marina L. and Thalassia testudinum Banks ex Konig. Aquatic Botany 63: 262-266.

Nogueira RE, Pereira OL, Kasuya MCM, Lanna MCS, Mendonça MP. 2005. Fungos micorrízicos associados a orquídeas em campos rupestres na região do Quadrilátero Ferrífero, MG, Brasil. Acta Botanica Brasilica 19: 417-424.

Nordby HE, Nemec S, Nagy S. 1981. Fatty acid and sterols associated with Citrus root mycorrhizae. Journal of Agricultural Food Chemistry 29: 396-401.

Ohki T, Yonezawa M, Hashiba T, Masuya H, Usuki F, Narisawa K. 2002. Colonization process of the root endophytic fungus Heteroconium chaetospira in roots of Chinese cabbage. Mycoscience 43: 191-194.

Olsson PA, Larsson L, Bago B, Wallander H, Aarle IM. 2003. Ergosterol and fatty acids for biomass estimation of mycorrhizal fungi. New Phytologist 159: 7-10.

Parniske M. 2008. Arbuscular mycorrhiza: the mother of plant root endosymbioses. Nature Reviews Microbiology 6: 763-775.

Peña-Venegas CP, Cardona GI, Arguelles JH, Arcos AL. 2007. Micorrizas arbusculares del sur de la Amazonia colombiana y su relación con algunos factores fisicoquímicos y biológicos del suelo. Acta Amazonica 37: $327-336$
Peterson RL, Wagg C, Pautler M. 2008. Associations between microfungal endophytes and roots: do structural features indicate function? Canadian Journal of Botany 86: 445-456.

Pietikäinen A, Kytöviita M-M, Vuoti U. 2005. Mycorrhiza and seedling establishment in a subarctic meadow: Effects of fertilization and defoliation. Journal of Vegetation Science 16: 175-182.

Postma JW, Olsson PA, Falkemgren-Grerup U. 2007. Root colonization by arbuscular mycorrhizal, fine endophytic and dark septate fungi across a pH gradient in acid beech forests. Soil Biology and Biochemistry 39: 400-408

Pott VJ, Pott A. 2000. Plantas aquáticas do Pantanal. Corumbá, Embrapa: Centro de Pesquisa Agropecuária do Pantanal; Brasília, Embrapa: Comunicação para Transferência de Tecnologia.

Radhika KP, Rodrigues BF. 2007. Arbuscular mycorrhizae in association with aquatic and marshy plant species in Goa, India. Aquatic Botany 86: 291-294

Ragupathy S, Mohankumar V, Mahadevan A. 1990. Occurrence of vesiculararbuscular mycorrhizae in tropical hydrophytes. Aquatic Botany 36: 287-291.

Rains KC, Nadkarni NM, Bledsoe CS. 2003. Epiphytic and terrestrial mycorrhizas in a lower montane Costa Rican cloud forest. Mycorrhiza 13: $257-264$

Ray AM, Inouye RS. 2006. Effects of water-level fluctuations on the arbuscular mycorrhizal colonization of Typha latifolia L. Aquatic Botany 84: 210-216.

Rodriguez RJ, White FA Jr, Arnold AE, Redman RS. 2009. Fungal endophytes: diversity and functional roles. New Phytologist 182: 314-330.

Ruotsalainen AL, Markkola A, Kozlov MV. 2007. Root fungal colonization in Deschampsia flexuosa: Effects of pollution and neighbouring trees. Environmental Pollution 147: 723-728.

Ruotsalainen AL, Väre H, Vestberg M. 2002. Seasonality of root fungal colonization in low-alpine herbs. Mycorrhiza 12: 29-36.

Santos BA, Silva GA, Maia LC, Alves MV. 2000. Mycorrhizae in Monocotyledonae of Northeast Brazil: subclasses Alismatidae, Arecidae and Zingiberidae. Mycorrhiza 10: 151-153.

Schübler A, Schwarzott D, Walker C. 2001. A new fungal phylum, the Glomeromycota: phylogeny and evolution. Mycological Research 102: 1413-1421.

Scremin-Dias E. 2009. Tropical aquatic plants: morphoanatomical adaptations. In: Del-Claro K., Oliveira PS, Rico-Gray V. (eds.) Tropical biology and conservation management. Vol. 1, Encyclopedia of life support systems. Oxford, Eolss Publishers Co. Ltd. p. 84-132.

Silva GA, Trufem SFB, Saggin Júnior O, Maia, LC. 2005. Arbuscular mycorrhizal fungi in a semiarid copper mining area in Brazil. Mycorrhiza 15: 47-53.

Smith SE, Read DJ. 2008. Mycorrhizal symbiosis. San Diego, Academic Press Inc.

Solaiman, Z. 2014. Contribution of arbuscular mycorrhizal fungi to soil carbon sequestration. In: Solaiman ZM, Abbott LK, Varma A. (eds.) Mycorrhizal Fungi: use in sustainable agriculture and land restoration. Vol. 41. Soil Biology. Berlin, Springer. p. 287-296.

Sondergaard M, Laegaard S. 1977. Vesicular-arbuscular mycorrhiza in some aquatic vascular plants. Nature 268: 232-233.

Souza MFL. 2003. Brazilian atlantic rainforest remnants and mycorrhizal simbiosis- implications for reforestation. A case study in Sergipe, Northeast Brazil. 2003. PhD Thesis, Bremer University, Bremer.

Sraj-Krzic N, Pongrac P, Klemenc M, Kladnik A, Regvar M, Gaberscik A. 2006. Mycorrhizal colonisation in plants from intermittent aquatic habitats. Aquatic Botany 85: 331-336.

Stevens KJ, Spender SW, Peterson RL. 2002. Phosphorous, arbuscular mycorrhizal fungi and performance of the wetland plant Lythrum salicaria L. under inundated conditions. Mycorrhiza 12: 277-283.

Stevens KJ, Wall CB, Janssen JA. 2011. Effects of arbuscular mycorrhizal fungi on seedling growth and development of two wetland plants, Bidens frondosa L. and Eclipta prostrata (L.) L. grown under three levels of water availability. Mycorrhiza 21: 279-288. 
Tanner CC, Clayton JS. 1985. Effects of vesicular-arbuscular mycorrhizas on growth and nutrition of a submerged aquatic plant. Aquatic Botany 22: $377-386$

Thomaz SM, Bini LM, Pagioro TA, Murphy KJ, Santos AM, Souza DC. 2004. Aquatic macrophytes: diversity, biomass and decomposition. In: Thomaz SM, Agostinho AA, Hahn NS. (ed.) The upper Paraná River and its Floodplain: physical aspects, ecology and conservation. Leiden, Backhuys Publishers. p. 331-351.

Trowbridge J, Jumpponen A. 2004. Fungal colonization of shrub willow roots at the forefront of a receding glacier. Mycorrhiza 14: 283-293.

Urcelay C. 2002. Co-occurrence of three fungal root symbionts in Gaultheria poeppiggi DC in Central Argentina. Mycorrhiza 12: 89-92.

Valdés M, Guerrero EB, Martínez L, Víquez RH. 2011. The root colonizing fungi of the terrestrial orchid Cypripedium irapeanum. Lankesteriana 11: 15-21.

Wagg C, Pautler M, Massicotte HB, Peterson L. 2008. The co-occurrence of ectomycorrhizal, arbuscular mycorrhizal, and dark septate fungi in seedlings of four members of the Pinaceae. Mycorrhiza 18: 103-110.

Wang B, Qiu Y-L. 2006. Phylogenetic distribution and evolution of mycorrhizas in land plants. Mycorrhiza 16: 299-363.
Wang YT, Qiu Q, Yang ZY, et al. 2010. Arbuscular mycorrhizal fungi in two mangroves in South China. Plant and Soil 331:181-191.

Weete JD, Gandhi SR. 1996. Biochemistry and molecular biology of fungal sterols. In: Brambl R, Marzluf G. (eds.) The mycota III: biochemistry and molecular biology. Berlin, Springer. p. 421-438.

Weishampel PA, Bedford BL. 2006. Wetland dicots and monocots differ in colonization by arbuscular mycorrhizal fungi and dark septate endophytes. Mycorrhiza 16: 495-502.

White JA, Charvat I. 1999.The mycorrhizal status of an emergent aquatic, Lythrum salicaria L., at different levels of phosphorous availability. Mycorrhiza 9: 181-197.

Wigand C, Stevenson JC. 1997. Facilitation of phosphate assimilation by aquatic mycorrhizae of Vallisneria americana Michx. Hydrobiologia 242: 35-41.

Wigand C, Andersen FO, Christensen KK, Holmer M, Jensen HS. 1998. Endomycorrhizae of isoetids along a biogeochemical gradient. Limnology and Oceanography 43: 508-515.

Wu L, Guo S. 2008. Interaction between an isolate of dark-septate fungi and its host plant Saussurea involucrate. Mycorrhiza 18: 79-85. 